\title{
Maternal Mortality Among American Indian/Alaska Native Women: A Scoping Review
}

\author{
Jennifer L. Heck, PhD, RNC-NIC, CNE, Emily J. Jones, PhD, RNC-OB, FAHA, FPCNA, \\ Diane Bohn, PhD, CNM, FACNM, ${ }^{2}$ Shondra McCage, MPH, MCHES, ${ }^{3}$ \\ Judy Goforth Parker, PhD, APRN-NP, FACHE, ${ }^{4}$ Mahate Parker, MD, ${ }^{5}$ \\ Stephanie L. Pierce, MD, MS, ${ }^{6}$ and Jacquelyn Campbell, PhD, RN, FAAN ${ }^{7}$
}

\section{Abstract}

Background: Maternal mortality decreased globally by about $38 \%$ between 2000 and 2017, yet, it continues to climb in the United States. Gaping disparities exist in U.S. maternal mortality between white (referent group) and minority women. Despite important and appropriate attention to disparities for black women, almost no attention has been given to American Indian/Alaska Native (AI/AN) women. The purpose of this scoping review is to synthesize available literature concerning AI/AN maternal mortality.

Methods: Databases were searched using the terms maternal mortality and pregnancy-related death, each paired with American Indian, Native American, Alaska Native, Inuit, and Indigenous. Criteria (e.g., hemorrhage) were paired with initial search terms. Next, pregnancy-associated death was paired with American Indian, Native American, Alaska Native, Inuit, and Indigenous. Criteria in this category were homicide, suicide, and substance use.

Results: The three leading causes of AI/AN pregnancy-related maternal mortality are hemorrhage, cardiomyopathies, and hypertensive disorders of pregnancy. AI/AN maternal mortality data for homicide and suicide consistently include small samples and often categorize AI/AN maternal deaths in an "Other" race/ethnicity, which precludes targeted AI/AN data analysis. No studies that reported AI/AN maternal mortality as a result of substance use were found. Health care characteristics such as quality, access, and location also may influence maternal outcomes and maternal mortality.

Conclusions: Despite AI/AN maternal mortality being disproportionately high compared to other racial/ethnic groups, relatively little is known about root causes.

Keywords: maternal mortality, maternal deaths, American Indian/Alaska Native, pregnancy-related maternal mortality, pregnancy-associated maternal mortality

\footnotetext{
${ }^{1}$ Fran and Earl Ziegler College of Nursing, University of Oklahoma Health Sciences Center, Oklahoma City, Oklahoma, USA.

${ }^{2}$ Cass Lake Indian Health Service, Cass Lake, Minnesota, USA.

${ }^{3}$ Hudson College of Public Health, University of Oklahoma Health Sciences Center, Oklahoma City, Oklahoma, USA.

${ }^{4}$ Chickasaw Nation Department of Health, Ada, Oklahoma, USA.

${ }^{5}$ OB Hospitalist Group, Greenville, South Carolina, USA.

${ }^{6}$ Department of Maternal-Fetal Medicine, College of Medicine, University of Oklahoma Health Sciences Center, Oklahoma City, Oklahoma, USA.

${ }^{7}$ Johns Hopkins University School of Nursing, Baltimore, Maryland, USA.

(C) Jennifer L. Heck et al. 2021; Published by Mary Ann Liebert, Inc. This Open Access article is distributed under the terms of the Creative Commons Attribution Noncommercial License (http://creativecommons.org/licenses/by-nc/4.0/) which permits any noncommercial use, distribution, and reproduction in any medium, provided the original author(s) and the source are cited.
}

Correction added on February 19, 2021 after first online publication of November 18, 2020: The article reflects Open Access, with copyright transferring to the author(s), and a Creative Commons Attribution Noncommercial License (CC-BY-NC) added (http:// creativecommons.org/licenses/by-nc/4.0/). 


\section{Introduction}

A FEBruARY 2020 headline read: "She hoped to shine a light on maternal mortality among Native Americans. Instead, she became a statistic of it." Stephanie Snook's story followed. The Washington State resident, member of the Alaskan Tsimshian and Tlingit tribes, and 37-year-old mother of two was pregnant with twins. An activist for U.S. Indigenous women's issues, she agreed to an NBC News interview for an article about the remarkably high Indigenous maternal mortality. Tragically, Stephanie developed cardiac arrest and died before her interview, only a few weeks before her scheduled cesarean birth. ${ }^{1}$

An indicator of a society's health, the maternal mortality ratio (MMR; maternal deaths per 100,000 live births) decreased globally by about $38 \%$ between 2000 and $2017,{ }^{2}$ yet, it continues to climb in the United States. Ranked worst in the developed world, the United States reports almost 700 pregnancy-related deaths annually. ${ }^{3}$ In 2018, the U.S. MMR was $17.4,{ }^{4}$ with $60 \%$ of these deaths deemed preventable. ${ }^{5}$

Gaping disparities exist in U.S. maternal mortality between white (referent group) and minority women. The Centers for Disease Control and Prevention's Pregnancy Mortality Surveillance System (PMSS) data (2007-2016) show an overall pregnancy-related mortality ratio (PRMR; pregnancy-related deaths per 100,000 live births) of 16.7 for the general population of U.S. women; the PRMR for white women was 12.7. ${ }^{3}$ For non-Hispanic black and American Indian/Alaska Native (AI/AN) women, PRMR was 40.8 and 29.7, respectively, ${ }^{3}$ revealing a persistent racial/ethnic disparity. Although education can be protective, AI/AN women with some college education had higher PRMR than all other racial/ethnic groups with less than a high school diploma. ${ }^{3}$ Despite important and appropriate attention to disparities for black women, almost no attention has been given to $\mathrm{AI} / \mathrm{AN}$ women.

The purpose of this scoping review is to synthesize available literature concerning $\mathrm{AI} / \mathrm{AN}$ maternal mortality. Specific aims are to determine leading cause(s) of AI/AN pregnancy-related and pregnancy-associated maternal mortality $^{6}$ (Table 1), identify and analyze gaps in the literature, and recommend directions for future research.

Table 1. Maternal Mortality Terminology

\begin{tabular}{lc} 
Term & $\begin{array}{c}\text { Definition for the purposes } \\
\text { of this study }\end{array}$ \\
\hline $\begin{array}{c}\text { Pregnancy-associated } \\
\text { death }\end{array}$ & $\begin{array}{c}\text { The death of a woman while } \\
\text { pregnant or within 1 year } \\
\text { of termination of pregnancy } \\
\text { irrespective of cause. } \\
\text { Pregnancy-related } \\
\text { death }\end{array}$ \\
$\begin{array}{c}\text { The death of a woman while } \\
\text { pregnant or within 1 year } \\
\text { of termination of pregnancy, } \\
\text { irrespective of the duration and } \\
\text { site of the pregnancy, from any } \\
\text { cause related to or aggravated by } \\
\text { her pregnancy or its management, } \\
\text { but not from accidental or } \\
\text { incidental causes. }\end{array}$
\end{tabular}

Source: Centers for Disease Control and Prevention (CDC). ${ }^{6}$

\section{Background and Significance}

$\mathrm{AI} / \mathrm{AN}$ people experience unequal rates of chronic disease and mortality, as well as poorer health outcomes. ${ }^{7} \mathrm{AI} / \mathrm{AN}$ life expectancy at birth is 5.5 years less than the general U.S. population. ${ }^{8}$ Since the colonization of America, certainly the greatest insult to $\mathrm{AI} / \mathrm{AN}$ health, health disparities have persisted. ${ }^{9}$ Colonization introduced destruction through wars, disease, and loss of land-all resulting in the significant loss of life and decimation of populations. ${ }^{9,10}$ Later, such federal policies as the reservation system and assimilation through boarding schools perpetuated social injustice and worsened AI/AN health. ${ }^{9}$

AI/AN people have a unique history with the U.S. federal government. Treaties promised health care and other services to $\mathrm{AI} / \mathrm{AN}$ people in exchange for natural resources and vast tracts of land. ${ }^{11}$ Established in 1955, the Indian Health Service (IHS) administers comprehensive health services to 574 federally recognized tribes. ${ }^{12}$ Resource deficiency and underfunding, however, continue to impede optimal health services, partly from inadequate numbers of providers and dwindling numbers of hospitals as facilities age and close. ${ }^{13}$ Furthermore, not all AI/AN tribes are federally recognized and some are therefore ineligible for IHS services. In addition, urban AI/AN residents often do not have access to IHS services.

\section{Methods}

Using the PRISMA extension for scoping reviews checklist, ${ }^{14}$ we comprehensively assessed and synthesized the maternal mortality literature concerning AI/AN women. An $\mathrm{AI} / \mathrm{AN}$ woman was defined as any female who is a member of an Indigenous tribe, band, or nation who maintains affiliation or community attachment.

The search strategy included Cumulated Index to Nursing and Allied Health Literature (CINAHL) Complete, Google Scholar, MEDLINE, MEDLINE Complete, PsycARTICLES, Psychology \& Behavioral Sciences Collection, and PubMed databases, searched up to March 2020. Initial search terms were maternal mortality and pregnancy-related death, each paired with American Indian, Native American, Alaska Native, Inuit, and Indigenous. Next, specific criteria (e.g., hemorrhage) were paired with the initial search terms, based on CDC's mutually exclusive categories of pregnancy-related causes of death ${ }^{5}$ (Table 2). Next, pregnancy-associated death was paired with American Indian, Native American, Alaska Native, Inuit, and Indigenous. Specific criteria in this category were homicide, suicide, and substance use.

Abstracts were reviewed to identify relevant articles, and reports were read in full if deemed relevant or if their

Table 2. Pregnancy-Related Causes of Death

\author{
Hemorrhage \\ Infection \\ Amniotic fluid embolism \\ Thrombotic pulmonary or other embolism \\ Hypertensive disorders of pregnancy \\ Anesthesia complications \\ Cerebrovascular accidents \\ Cardiomyopathy \\ Other CV conditions \\ Other non-CV medical conditions
}

$\mathrm{CV}$, cardiovascular

Source: Petersen et al. ${ }^{5}$ 
FIG. 1. Flow diagram of study selection that sequences the review process. CINAHL, Cumulated Index to Nursing and Allied Health Literature;

MEDLINE, online counterpart to MEDLARS (Medical Literature Analysis and Retrieval System); the U.S. National Library of Medicine ${ }^{\circledR}$ premier bibliographic database. Adapted from Moher et al.

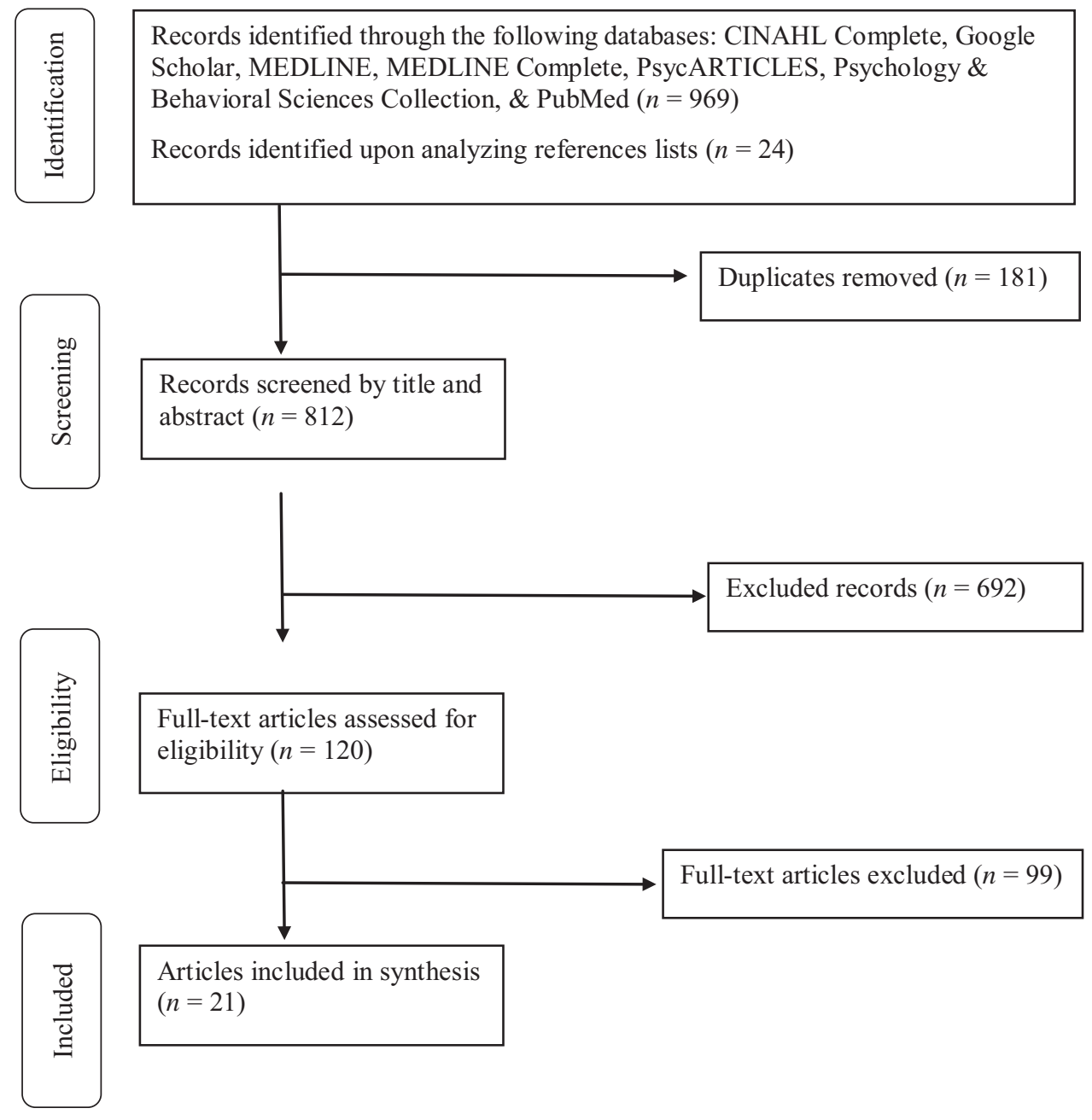

relevance was uncertain. Irrelevant, duplicate, and nonEnglish language articles and research outside the United States were excluded. Additional citations were retrieved manually from selected articles' reference lists. The search produced a final yield of 21 articles (Fig. 1).

\section{Results}

Results are discussed according to search categories (Tables 3 5). Not all reviewed studies used the racial/ethnic category "American Indian/Alaska Native." Some used "American Indian" or "Native American" alone; therefore, our results do also. No studies discussed Alaska Native women alone.

\section{Pregnancy-related maternal mortality}

The three leading causes of AI/AN pregnancy-related maternal mortality are hemorrhage (19.7\%), cardiomyopathies $(14.5 \%)$, and hypertensive disorders of pregnancy $(12.8 \%){ }^{3}$

Cardiovascular complications. Cardiovascular disease is the leading cause of U.S. maternal death, responsible for over $33 \%$ of pregnancy-related deaths. ${ }^{5}$ The national trends of delayed childbearing and more chronic disease mean more women enter pregnancy with medical comorbidities (e.g., diabetes, obesity, and hypertension), and prevalence of these conditions is higher among $\mathrm{AI} / \mathrm{AN}$ women. ${ }^{18}$ $14.5 \%$ of $\mathrm{AI} / \mathrm{AN}$ pregnancy-related maternal mortality, representing a greater proportionate cause of death than any other racial/ethnic group; among black and white women, ity, respectively. Other cardiovascular complications (e.g., congenital heart disease), accounted for $11.1 \%$ of $\mathrm{AI} / \mathrm{AN}$ pregnancy-related mortality, a smaller proportionate cause of death than other racial/ethnic groups. ${ }^{3}$

Obstetric/noncardiovascular complications. In PMSS data (2007-2016), hemorrhage (19.7\%) and hypertensive disorders of pregnancy $(12.8 \%)$ accounted for a significantly higher proportion of $\mathrm{AI} / \mathrm{AN}$ than white pregnancy-related maternal mortality $(p<0.05)$, higher than all other racial/ethnic groups. White rates of pregnancy-related maternal mortality for these conditions were $9.1 \%$ and $6.7 \%$, respectively. ${ }^{3}$

In a retrospective study of 1062 women, postpartum hemorrhage and uterine atony were significantly higher in Native American than white women. ${ }^{15}$ Higher rates of severe maternal morbidity in Native American women are driven largely by blood transfusions. ${ }^{15}$ The reasons for increased postpartum hemorrhage and more blood loss in AI/AN women are unknown. Further research is urgently needed in this area.

$\mathrm{AI} / \mathrm{AN}$ women in Washington State had a $17 \%$ increased risk of preeclampsia compared to white women, even after adjusting for age, socioeconomic status, and smoking. ${ }^{19}$
In PMSS data (2007-2016) cardiomyopathy accounted for cardiomyopathy accounted for $14.2 \%$ and $10.2 \%$ of mortal- 
Table 3. Summary of Pregnancy-Related Causes of Death Studies $(N=6)$

\begin{tabular}{|c|c|c|c|c|c|}
\hline \multirow{2}{*}{$\begin{array}{l}\text { First author } \\
(\text { year) })^{\text {Ref. }}\end{array}$} & \multirow[b]{2}{*}{ Design } & \multirow[b]{2}{*}{ Location } & \multirow[b]{2}{*}{ Sample } & $\begin{array}{l}R / E \text { reported } \\
\text { in results }\end{array}$ & \multirow{2}{*}{$\begin{array}{c}\text { Pregnancy-related cause }(s) \\
\text { of death studied }\end{array}$} \\
\hline & & & & $\overline{A I / A N}$ "Other" & \\
\hline $\begin{array}{l}\text { Chalouhi } \\
\qquad(2015)^{15}\end{array}$ & $\begin{array}{l}\text { Retrospective } \\
\text { analysis }\end{array}$ & $\begin{array}{l}\text { Gallup, } \\
\text { NM }\end{array}$ & $\begin{array}{l}\text { Inpatient obstetric charts, } \\
\text { Rehoboth McKinley } \\
\text { Hospital, 2009-2012 } \\
(N=1062)\end{array}$ & $\mathrm{X}$ & Hemorrhage (postpartum) \\
\hline $\begin{array}{l}\text { Hsieh } \\
\qquad(2020)^{16}\end{array}$ & $\begin{array}{l}\text { Retrospective } \\
\text { analysis }\end{array}$ & $\begin{array}{l}\text { United } \\
\text { States }\end{array}$ & $\begin{array}{l}\text { National inpatient sample, } \\
2003-2013(N=87,076)\end{array}$ & $\mathrm{X}$ & Anesthesia complications \\
\hline $\operatorname{Kim}_{(2009)^{17}}$ & $\begin{array}{l}\text { Retrospective } \\
\text { analysis }\end{array}$ & Alaska & $\begin{array}{l}\text { PRAMS, 2000-2003 } \\
\quad(N=5458)\end{array}$ & $\mathrm{X}$ & $\begin{array}{l}\text { N/A_cigarette and } \\
\text { smokeless tobacco use } \\
\text { before, during, and after } \\
\text { pregnancy }\end{array}$ \\
\hline $\begin{array}{l}\text { Kozhimannil } \\
\qquad(2020)^{18}\end{array}$ & $\begin{array}{l}\text { Pooled, cross- } \\
\text { sectional } \\
\text { analysis }\end{array}$ & $\begin{array}{l}\text { United } \\
\text { States }\end{array}$ & $\begin{array}{l}\text { National inpatient sample, } \\
\text { 2012-2015 } \\
(N=1,417,500)\end{array}$ & $\mathrm{X}$ & Other CV conditions \\
\hline $\begin{array}{l}\text { Petersen } \\
\quad(2019)^{3}\end{array}$ & $\begin{array}{l}\text { Retrospective } \\
\text { analysis }\end{array}$ & $\begin{array}{l}\text { United } \\
\text { States }\end{array}$ & $\begin{array}{l}\text { PMSS, 2007-2016 } \\
\quad(N=6765)\end{array}$ & $\mathrm{X}$ & $\begin{array}{l}\text { Hemorrhage, infection, } \\
\text { amniotic fluid embolism, } \\
\text { thrombotic, pulmonary, or } \\
\text { other emboli, hypertensive } \\
\text { disorders of pregnancy, } \\
\text { anesthesia complications, } \\
\text { cerebrovascular accidents, } \\
\text { cardiomyopathy, other CV } \\
\text { conditions, other non-CV } \\
\text { medical conditions }\end{array}$ \\
\hline $\begin{array}{l}\text { Zamora- } \\
\text { Kapoor } \\
(2016)^{19}\end{array}$ & $\begin{array}{l}\text { Retrospective } \\
\text { cohort study }\end{array}$ & $\begin{array}{l}\text { Washington } \\
\text { State }\end{array}$ & $\begin{array}{l}\text { Linked birth-hospital } \\
\text { discharge data, 2003- } \\
2013(N=71,080)\end{array}$ & $\mathrm{X}$ & $\begin{array}{l}\text { Hypertensive disorders of } \\
\text { pregnancy (preeclampsia) }\end{array}$ \\
\hline
\end{tabular}

AI/AN, American Indian/Alaska Native; N/A, not applicable; PMSS, Pregnancy Mortality Surveillance System; PRAMS, Pregnancy Risk Assessment Monitoring System; R/E, race/ethnicity.

Obesity was a confounder, highlighting an important risk factor for pregnancy-related morbidity and mortality. ${ }^{19} \mathrm{Hy}-$ pertensive disorders first diagnosed during pregnancy were also higher for $\mathrm{AI} / \mathrm{AN}$ than white women $(12.8 \%$ and $6.7 \%$, respectively, $p<0.05){ }^{3}$ Deaths related to noncardiovascular medical conditions (e.g., renal) were similar between AI/AN and white women. ${ }^{3}$

In a sample of 89,076 women who had cesarean deliveries with epidural catheters, anesthesia complications were more common in Native American women than other racial/ethnic groups; no difference existed in rates of amniotic fluid embolism. ${ }^{16}$ Contrasting other causes of maternal death, AI/AN women had a significantly lower proportion of infection compared with white women $(8.5 \%$ and $15.2 \%$, respectively, $p<0.05){ }^{3}$

\section{Pregnancy-associated maternal mortality}

Homicide. Maternal deaths attributable to homicide, as well as suicide, often are associated with intimate partner violence (IPV). ${ }^{26,35}$ For instance, $45.3 \%$ of pregnancy-associated homicides are associated with IPV. ${ }^{26}$ Lifetime and 12 -month prevalence rates of IPV are consistently higher for AI/AN (47.5\%) than white women $(37.3 \%)$, and AI/AN women have the highest reported IPV prevalence of all other racial/ethnic groups. ${ }^{36}$

Eight studies explored AI/AN maternal deaths by homicide; because of data privacy policies, all studies used an "Other" racial/ethnic category instead of AI/AN, because there were too few cases to discuss. Homicide rates for "Other" women ranged from $0 \%$ to $3.8 \% .^{20-23,26-28}$
Although this rate appears consistently low, homicide remains a leading cause of pregnancy-associated injury deaths in the United States. ${ }^{22,26,35}$ Disparate numbers of missing and murdered Indigenous women ${ }^{37}$ suggest that homicide may be responsible for more pregnancy-associated $\mathrm{AI} / \mathrm{AN}$ deaths than has been recognized to date.

Suicide. A leading cause of death and disability in the United States, suicide among AI/AN people is higher than all other racial/ethnic groups. ${ }^{7}$ An intimate partner conflict potentially contributed to $54.3 \%$ of pregnancy-associated suicides. ${ }^{26}$ Nine studies investigated AI/AN maternal deaths by suicide. Mirroring homicide data, small samples and categorization as "Other" race/ethnicity precludes targeted AI/AN data analysis.

Reporting of AI/AN maternal suicide deaths is inconsistent. Palladino et al. ${ }^{26}$ reported that prenatal and postpartum suicide disproportionately affects $\mathrm{AI} / \mathrm{AN}$ and white women, yet, others report little or no risk for AI/AN women. ${ }^{20,21,23-25,27}$ This result could be explained partially by the use of an "Other" race/ethnicity category; Palladino et al. was the only study that reported $\mathrm{AI} / \mathrm{AN}$ women as $\mathrm{AI} / \mathrm{AN}$ versus "Other."

One study combined suicide with accidental overdose and reported 4 out of 59 maternal deaths for "non-Hispanic Others" 25 ; although this report was likely for statistical purposes, it only complicates matters. One study that included AI/AN maternal deaths as "Other" still reported too few suicides to discuss. ${ }^{21}$ Suicide rates for "Other" women (an unknown portion of which were AI/AN) ranged from $0 \%$ to $13.3 \% .^{20,23,24,27,28,38}$ 
Table 4. Summary of Pregnancy-Associated Causes of Death Studies $(N=9)$

\begin{tabular}{|c|c|c|c|c|c|c|c|c|}
\hline \multirow[b]{2}{*}{$\begin{array}{l}\text { First author } \\
\text { (year) }^{\text {Ref. }}\end{array}$} & \multirow[b]{2}{*}{ Design } & \multirow[b]{2}{*}{ Location } & \multirow[b]{2}{*}{ Sample } & \multicolumn{2}{|c|}{$\begin{array}{l}R / E \text { reported } \\
\text { in results }\end{array}$} & \multicolumn{3}{|c|}{$\begin{array}{l}\text { Pregnancy-associated } \\
\text { cause of death studied }\end{array}$} \\
\hline & & & & $A I / A N$ & "Other" & Homicide & Suicide & $\begin{array}{c}\text { Substance } \\
\text { use }\end{array}$ \\
\hline $\begin{array}{l}\text { Austin } \\
(2016)^{20}\end{array}$ & Case study & $\begin{array}{l}\text { North } \\
\text { Carolina }\end{array}$ & $\begin{array}{l}\text { North Carolina VDRS, } \\
2005-2011(N=84)\end{array}$ & & $X$ & $X$ & $X$ & \\
\hline $\begin{array}{l}\text { Bronson } \\
\quad(2017)^{21}\end{array}$ & Case study & Virginia & $\begin{array}{l}\text { Pregnancy-associated } \\
\text { deaths from Virginia's } \\
\text { Office of the Chief } \\
\text { Medical Examiner, } \\
\text { 1999-2005 }(N=309)\end{array}$ & & $X$ & $X$ & $X$ & \\
\hline $\begin{array}{l}\text { Chang } \\
(2005)^{22}\end{array}$ & $\begin{array}{l}\text { Secondary data } \\
\text { analysis }\end{array}$ & $\begin{array}{l}\text { United } \\
\text { States }\end{array}$ & $\begin{array}{l}\text { PMSS data, 1991-1999 } \\
\quad(N=7342)\end{array}$ & & $X$ & $X$ & & \\
\hline $\begin{array}{l}\text { Dannenberg } \\
(1995)^{23}\end{array}$ & Case study & NYC & $\begin{array}{l}\text { NYC medical examiner } \\
\text { records, 1987-1991 } \\
(N=2331)\end{array}$ & & $X$ & $X$ & $X$ & \\
\hline $\begin{array}{l}\text { Goldman- } \\
\text { Mellor } \\
(2019)^{24}\end{array}$ & $\begin{array}{l}\text { Retrospective, } \\
\text { population- } \\
\text { based } \\
\text { cohort study }\end{array}$ & California & $\begin{array}{l}\text { Data from California } \\
\text { Office of Statewide } \\
\text { Health Planning and } \\
\text { Development, 2010- } \\
2012(N=1,059,713)\end{array}$ & & $X$ & & $X$ & \\
\hline $\begin{array}{l}\text { Metz } \\
(2016)^{25}\end{array}$ & Case study & Colorado & $\begin{array}{l}\text { Death certificates, 2004- } \\
2012(N=211)\end{array}$ & & $X$ & & $X$ & $X$ \\
\hline $\begin{array}{l}\text { Palladino } \\
(2011)^{26}\end{array}$ & $\begin{array}{l}\text { Secondary data } \\
\text { analysis }\end{array}$ & $\begin{array}{l}17 \text { U.S. } \\
\text { states }\end{array}$ & $\begin{array}{l}\text { Pregnancy-associated } \\
\text { violent deaths, National } \\
\text { VDRS, 2003-2007 } \\
(N=233)\end{array}$ & $X$ & & $X$ & $X$ & \\
\hline $\begin{array}{l}\text { Platner } \\
\quad(2016)^{27}\end{array}$ & $\begin{array}{l}\text { Population-based } \\
\text { cohort study }\end{array}$ & Georgia & $\begin{array}{l}\text { Pregnancy-associated } \\
\text { deaths via Georgia's } \\
\text { Office of Health } \\
\text { Information for } \\
\text { Planning, 2010-2012 } \\
(N=262)\end{array}$ & & $X$ & $X$ & $X$ & $X$ \\
\hline $\begin{array}{l}\text { Wallace } \\
(2016)^{28}\end{array}$ & $\begin{array}{l}\text { Retrospective } \\
\text { analysis }\end{array}$ & $\begin{array}{l}37 \text { U.S. } \\
\text { states }\end{array}$ & $\begin{array}{l}\text { Death certificates, 2005- } \\
2010(N=465,097)\end{array}$ & & $X$ & $\mathrm{X}$ & $X$ & \\
\hline
\end{tabular}

NYC, New York City; VDRS, Violent Death Reporting System.

Substance use. We found no studies examining AI/AN pregnancy-associated maternal mortality from substance use. Most data examine prevalence of tobacco use, which is higher for AI/AN than white women. ${ }^{17}$ In Alaska, prenatal tobacco use was threefold higher for Alaska Native (43.4\%) than white women (13.4\%). ${ }^{17}$ Danielson et al. found markedly elevated risk of smoking, alcohol, and illicit drug use during pregnancy among AI/AN women compared to white women. ${ }^{39}$ The AI/AN to white ratios for use of these substances were 2.6, 6.4, and 3.1, respectively. ${ }^{39}$ In a report of overdose deaths, AI/AN rates for all opioids were higher than all other racial/ethnic groups except whites; rates were not disaggregated by gender within racial/ethnic categories. ${ }^{40}$ These data suggest that overdose may account for more pregnancy-associated $\mathrm{AI} / \mathrm{AN}$ deaths than is generally recognized.

\section{Socioecological and health care influences}

Poor perinatal outcomes are associated with poverty, lack of education, and neighborhood-level factors. ${ }^{41}$ Understanding the complex interactions among social determinants (root causes) of health is crucial to understanding effects on maternal outcomes. ${ }^{42}$ Health care characteristics such as quality, access, and location may also influence maternal outcomes.
Health care quality. Disparities in health care quality related to maternal mortality have been examined largely from a racial perspective of white versus nonwhite or black. Although information specific to $\mathrm{AI} / \mathrm{AN}$ people is lacking, existing models may be applicable. Howell ${ }^{43}$ developed a conceptual model depicting pathways to racial/ethnic disparities in severe maternal morbidity and mortality that examines patient, neighborhood, provider, and system-level factors.

Prenatal care. Adequate prenatal care (PNC) improves perinatal outcomes ${ }^{44}$ yet, about $13 \%$ of AI/AN women receive late (i.e., third trimester initiation) or no PNC, compared to $4.5 \%$ of white women. ${ }^{33}$ In urban settings, AI/AN women received late or no PNC at twice the rate of all other women combined. ${ }^{30}$ This may be explained partially by barriers they already experience, such as lack of health insurance or reliable transportation. ${ }^{32}$

Poor understanding of AI/AN culture and inability to tailor care to the unique needs of $\mathrm{AI} / \mathrm{AN}$ women are provider characteristics that negatively affect PNC quality. ${ }^{34} \mathrm{AI} / \mathrm{AN}$ women reported such negative provider experiences as disrespect and being stereotyped as "drunks and drug users." $32,34,45$ The inability to see one provider throughout pregnancy, providers that seemed too busy to address concerns, and hearing negative stories from others were additional barriers. ${ }^{32}$ 
Table 5. Summary of Socioecological and Health Care Influences Studies $(N=6)$

\begin{tabular}{|c|c|c|c|c|c|c|c|c|c|}
\hline \multirow[b]{2}{*}{$\begin{array}{l}\text { First author } \\
(\text { year })^{\text {Ref. }}\end{array}$} & \multirow[b]{2}{*}{ Design } & \multirow[b]{2}{*}{ Location } & \multirow[b]{2}{*}{ Sample } & \multicolumn{2}{|c|}{$\begin{array}{l}R / E \text { reported } \\
\text { in results }\end{array}$} & \multicolumn{4}{|c|}{$\begin{array}{l}\text { Socioecological/health care } \\
\text { influence(s) studied }\end{array}$} \\
\hline & & & & $A I / A N$ & "Other", & $\begin{array}{l}\text { Health } \\
\text { care } \\
\text { quality }\end{array}$ & $P N C$ & $\begin{array}{l}\text { Rural- } \\
\text { urban }\end{array}$ & Other \\
\hline $\begin{array}{l}\text { Baldwin } \\
\quad(2009)^{29}\end{array}$ & $\begin{array}{l}\text { Retrospective } \\
\text { analysis }\end{array}$ & $\begin{array}{r}\text { Rural U.S. } \\
\text { counties }\end{array}$ & $\begin{array}{l}\text { NLBID data, 1985-1987; } \\
\quad 1989-1991 ; 1995-1997 \\
(N=5,249,597)\end{array}$ & $\mathrm{X}$ & & & $X$ & $X$ & $X$ \\
\hline $\begin{array}{l}\text { Castor } \\
\qquad(2006)^{30}\end{array}$ & Retrospective & $\begin{array}{l}\text { United } \\
\text { States }\end{array}$ & $\begin{array}{l}2000 \text { U.S. Census data } \\
\quad(N=4.1 \text { million); death } \\
\text { certificate }(1990-1999 ; \\
N=100,000), \text { birth } \\
\text { certificate }(1991-2000 ; \\
N=400,000), \text { and linked } \\
\text { infant death/natality } \\
\text { (1995-2000; } N=\text { NR) data } \\
\text { from NCHS }\end{array}$ & $X$ & & & $\mathrm{X}$ & $\mathrm{X}$ & $\mathrm{X}$ \\
\hline $\begin{array}{l}\text { Grossman } \\
\quad(2002)^{31}\end{array}$ & $\begin{array}{l}\text { Retrospective } \\
\text { cohort study }\end{array}$ & $\begin{array}{l}\text { United } \\
\text { States }\end{array}$ & $\begin{array}{l}\text { Birth-death linked database } \\
\text { from NCHS, 1989-1991 } \\
\quad(N=148,482)\end{array}$ & $X$ & & & $X$ & $\mathrm{X}$ & $X$ \\
\hline $\begin{array}{l}\text { Hanson } \\
(2012)^{32}\end{array}$ & Qualitative & $\begin{array}{c}\text { Northern } \\
\text { Plains }\end{array}$ & $\begin{array}{l}\text { American Indian women, } \\
(N=58)\end{array}$ & $\mathrm{X}$ & & & $\mathrm{X}$ & & \\
\hline $\begin{array}{l}\text { Martin } \\
(2019)^{33}\end{array}$ & $\begin{array}{l}\text { Retrospective } \\
\text { analysis }\end{array}$ & $\begin{array}{l}\text { United } \\
\text { States }\end{array}$ & $\begin{array}{l}2018 \text { U.S. birth data } \\
(N=3,791,712)\end{array}$ & $X$ & & & $X$ & & \\
\hline $\begin{array}{l}\text { Wilder } \\
\text { Research } \\
(2015)^{34}\end{array}$ & Qualitative & Minnesota & $\begin{array}{l}\text { Two focus groups }(n=8 ; \\
n=4) \text { with American } \\
\text { Indian mothers; } \\
\text { interviews with Native } \\
\text { and non-Native providers } \\
(N=44)\end{array}$ & $X$ & & & $X$ & & $X$ \\
\hline
\end{tabular}

NCHS, National Center for Health Statistics; NLBID, National Linked Birth \& Infant Death; NR, not reported; PNC, prenatal care.

Relationships between PNC and maternal outcomes are complex, comprising more than simply timing and number of visits. Location can influence the likelihood of adequate PNC (operationalized with various measures); $14.4 \%$ of all urban $\mathrm{AI} / \mathrm{AN}$ women received inadequate $\mathrm{PNC}$, but rates ranged from $4.4 \%$ to $29.8 \%$ based on location. ${ }^{31}$ Even larger disparities appeared in rural settings, with $33.9 \%$ of $\mathrm{AI} / \mathrm{AN}$ women receiving inadequate PNC compared to $13.5 \%$ of white women. ${ }^{29}$

Rural-urban influences. Although rurality is associated with increased maternal morbidity and mortality, AI/AN maternal morbidity and mortality exceeded that for white women in both rural and urban locations. ${ }^{18}$ Also noted were increased rates of blood transfusion among AI/AN women, particularly in rural settings, ${ }^{18}$ which is consistent with other reports that blood transfusions appear to drive severe maternal morbidity. ${ }^{15}$ When blood transfusion, as the sole marker of severe maternal morbidity and mortality, was removed from the analysis, AI/AN women still experienced higher rates of severe maternal morbidity and mortality. ${ }^{18}$

\section{Discussion}

Despite AI/AN maternal mortality being disproportionately high compared to other racial/ethnic groups, relatively little is known about the root causes. Research examining causation points to higher rates of hemorrhage and pregnancyassociated hypertension (obesity may contribute), ${ }^{3}$ but these causes do not account entirely for the increase in deaths compared to other racial/ethnic groups. Even less is understood about AI/AN pregnancy-associated deaths, with divergent studies reporting that suicide disproportionately affects AI/AN women ${ }^{26}$ while others report the opposite. ${ }^{20,21,23-25,27}$ Mental illness contributes to U.S. maternal mortality and is a leading cause of death. ${ }^{46}$ Although suicide can be a consequence of mental illness such as depression, ${ }^{47}$ we found no studies exploring the relationship between depression and AI/AN maternal mortality. Given that AI/AN women experience more postpartum depression than white women, ${ }^{48-50}$ further investigation into postpartum depression and other mental illness as root causes is warranted. In addition, pregnancy-associated homicide deaths might be disproportionate among AI/AN women of childbearing age because they experience increased rates of IPV and homicide.

Historical trauma is considered a significant social determinant of health for AI/AN people, ${ }^{9,10}$ resulting from cumulative exposure to traumatic events produced by colonization. ${ }^{51}$ It manifests in subsequent generations as depression, substance use, diabetes, and other adversities that damage social determinants of health. ${ }^{52}$ Comorbidities such as mental illness and substance use increase the likelihood of maternal morbidity and mortality. ${ }^{42} \mathrm{IPV}$ is another cumulative trauma that can result in adverse physical and psychological effects.

Life expectancy at birth has increased among all U.S. racial/ethnic groups, yet, AI/AN people continue to die at younger ages than the general population. ${ }^{53}$ Consistent with the weathering hypothesis, this effect might be explained partially by barriers to quality health care that AI/AN people 
face. The weathering hypothesis suggests that cumulative stress from racism and socioeconomic disadvantage produces a weathering effect on health that can explain disparate outcomes. ${ }^{54}$ Weathering degrades health across the lifespan, making it more difficult for women of color to enter pregnancy in optimal health. ${ }^{55}$ Perhaps the same is true for maternal mortality; a recent analysis supports the weathering hypothesis for AI/AN and black women. ${ }^{3}$

Inequities in health care availability, access, and utilization warrant elucidation to decrease AI/AN maternal mortality $^{56}$ because systems-level factors (e.g., facility clinical processes) are linked to maternal morbidity and mortality. ${ }^{41}$ Widespread use of midwives could play a key role; on national and international levels, midwife-led care is an important contributor to improved quality of care and perinatal outcomes. ${ }^{55,57,58}$ Approaches to improve delivery might include care coordination, home visiting, telehealth, and peer support. $^{5,25}$ To reduce AI/AN maternal mortality and eliminate racial/ethnic disparities, provider-related factors such as inappropriate management and implicit bias must be addressed via targeted cultural humility, trauma-informed care, quality improvement, and other types of training. $5,34,55$

Although this scoping review focused on AI/AN maternal mortality, we identified many studies concerning AI/AN maternal morbidity linking preexisting health conditions (e.g., obesity) to increased mortality risk. AI/AN and black women reported the highest number of stressful life events in the year preceding childbirth, ${ }^{59}$ and stress and racism might influence maternal morbidity and mortality. ${ }^{60}$ Of all racial/ ethnic groups, AI/AN women were most likely to report having two or more risk factors (e.g., at-risk drinking, smoking) for adverse perinatal outcomes. ${ }^{61}$ Obesity, high school noncompletion, diabetes, and fewer than 10 prenatal visits have been linked to maternal mortality for some racial/ ethnic groups of women, ${ }^{62}$ but we found no evidence for AI/AN women specifically.

Consistent with long-standing data collection issues, ${ }^{63}$ we offer multiple reasons for AI/AN data paucity and limitations. The absolute number of AI/AN pregnancy-related and pregnancy-associated deaths is small. For example, in PMSS data analyses (2007-2016), only 117 AI/AN maternal deaths were reported. ${ }^{3}$ Studies examining pregnancy-related mortality often exclude deaths from trauma. ${ }^{64}$ In addition, with low numbers, cases are discussed together to protect confidentiality and privacy. ${ }^{21,26,38} \mathrm{AI} / \mathrm{AN}$ maternal deaths are classified in an "Other" racial/ethnic category where the $\mathrm{AI} / \mathrm{AN}$ proportion could be anywhere from $0 \%$ to $100 \%$, complicating interpretation of AI/AN maternal mortality. This lack of data prevents clear understanding and hindered us from determining leading cause(s) of AI/AN pregnancyassociated maternal mortality. Ultimately, this practice obstructs intervention development to address root causes of AI/AN maternal mortality.

Racial/ethnic misclassification on death certificates potentially leads to underreporting ${ }^{26}$ and compromised estimates of mortality, with as many as $45 \%$ of AI/AN deaths being misclassified as another race. Given the relatively small AI/AN population, even negligible misclassifications can markedly affect data analyses, ${ }^{65}$ likely resulting in an underestimation of $\mathrm{AI} / \mathrm{AN}$ maternal mortality.

Given the historical trauma ${ }^{10,66}$ and medical and research abuses $^{67}$ that AI/AN people have experienced, research teams are more successful when they elicit tribal interest and engage communities in setting research agendas. Research partnerships are more meaningful when teams include or are led by Indigenous researchers. For these reasons, communitybased participatory research (CBPR), or similar approaches that center on community needs, produces mutually beneficial outcomes and is often favored by tribes. ${ }^{68-70}$ CBPR has contributed to reducing health disparities while providing equity in research relationships with tribal groups. ${ }^{71}$

\section{Conclusion}

$\mathrm{AI} / \mathrm{AN}$ women die at disproportionate rates during and in the year following pregnancy compared to white women. Together, hemorrhage, cardiomyopathy, and hypertensive disorders of pregnancy might account for nearly half of $\mathrm{AI} / \mathrm{AN}$ pregnancy-related deaths, and drivers of severe maternal morbidity include obesity, diabetes, and blood transfusions. Homicide, suicide, and substance use, all linked to IPV, clearly contribute to AI/AN pregnancy-associated maternal mortality, yet, severe data limitations prohibit our understanding of true incidence and prevalence.

Although specific and cumulative impacts of social and structural determinants on AI/AN maternal mortality have received little attention, implications may be drawn cautiously from what is known about existing disparities. Inadequate PNC and culturally uninformed health care increase risk for AI/AN maternal mortality. Unequal care and structural racism undoubtedly affect U.S. maternal mortality, and the complex role of AI/AN identity in increased maternal mortality demands further examination. Investing in participatory research approaches and community-driven programs to improve early access to quality health care warrants further attention in diverse rural and urban tribal communities to optimize AI/AN maternal health. Amidst ongoing federal, state, and local efforts to address maternal mortality, researchers must use novel approaches to collect meaningful data, elucidate root causes, guide public health efforts, and inform policy to improve maternal health outcomes and reduce AI/AN maternal mortality. Until this is accomplished, history will continue to repeat itself.

\section{Disclaimer}

The information contained herein is not the official position of the IHS.

\section{Author Disclosure Statement}

All the authors disclose no competing, personal, or other financial interests.

\section{Funding Information}

No funding was received for this article.

\section{References}

1. Chuck E, Assefa H. She hoped to shine a light on maternal mortality among Native Americans. Instead, she became a statistic of it. NBC News, February 8, 2020. Available at: https://www.nbcnews.com/news/us-news/she-hoped-shinelight-maternal-mortality-among-native-americans-insteadn1131951 Accessed April 1, 2020. 
2. World Health Organization (WHO). Maternal mortality. 2019. Updated September 19, 2019. Available at: https:// www.who.int/news-room/fact-sheets/detail/maternal-mor tality Accessed April 5, 2020.

3. Petersen EE, Davis NL, Goodman D, et al. Racial/ethnic disparities in pregnancy-related deaths: United States, 2007-2016. MMWR Morb Mortal Wkly Rep 2019;68: $762-765$.

4. Centers for Disease Control and Prevention (CDC). Maternal mortality. 2019. Available at: https://www.cdc.gov/ nchs/maternal-mortality Accessed April 5, 2020.

5. Petersen EE, Davis NL, Goodman D, et al. Vital signs: Pregnancy-related deaths, United States, 2011-2015, and strategies for prevention, 13 states, 2013-2017. MMWR Morb Mortal Wkly Rep 2019;68:423-429.

6. Centers for Disease Control and Prevention (CDC). Strategies to reduce pregnancy-related deaths: From identification and review to action. 2001. Available at: www .amchp.org/programsandtopics/womens-health/Focus $\% 20$ Areas/MMR/Documents/2001-Strategies-to-Reduce-PRDeaths.pdf Accessed May 15, 2020.

7. Centers for Disease Control and Prevention (CDC). CDC health disparities and inequalities report: United States, 2013. MMWR Morb Mortal Wkly Rep 2013;62:1-187.

8. Indian Health Service (IHS). Indian Health disparities. 2016. Available at: www.ihs.gov/newsroom/factsheets/ disparities Accessed March 19, 2020.

9. Jones D. The persistance of American Indian health disparities. Am J Public Health 2006;96:2122-2134.

10. Sotero M. A conceptual model of historical trauma: Implications for public health practice and research. J Health Dispar Res Pract 2006;1:93-108.

11. The Oklahoma Academy. We can do better: Improving the health of the Oklahoma people. 2014. Available at: https:// okacademy.org/wp-content/uploads/2020/01/24-2014-Health .pdf Accessed March 13, 2020

12. Indian Health Service (IHS). Basis for health services. 2015. Available at: https://www.ihs.gov/newsroom/fact sheets/basisforhealthservices Accessed April 22, 2020.

13. Weaver C. Rx for ailing Indian Health Service: Changes in spending, recruitment. The Wall Street Journal. December 31, 2019. Available at: https://www.wsj.com/articles/rx-forailing-indian-health-service-changes-in-spending-recruitment11577804731 Accessed March 23, 2020.

14. Tricco AC, Lillie E, Zarin W, et al. PRISMA extension for scoping reviews (PRISMA-ScR): Checklist and explanation. Ann Intern Med 2018;169:467-473.

15. Chalouhi SE, Tarutis J, Barros G, Starke RM, Mozurkewich EL. Risk of postpartum hemorrhage among Native American women. Int J Gynecol Obstet 2015;131:269272.

16. Hsieh YC, Shah HR, Balasubramaniam P. The association of race with outcomes among parturients undergoing Cesarean section with perioperative epidural catheter placement: A nationwide analysis. Cureus 2020;12:e6652.

17. Kim SY, England L, Dietz P, Morrow B, Perham-Hester KA. Patterns of cigarette and smokeless tobacco use before, during, and after pregnancy among Alaska Native and White women in Alaska, 2000-2003. Matern Child Health J 2009; 14:365-372.

18. Kozhimannil KB, Interrante JD, Tofte AN, Admon LK. Severe maternal morbidity and mortality among Indigenous women in the United States. Obstet Gynecol 2020;135: 294-300.
19. Zamora-Kapoor A, Nelson LA, Buchwald DS, Walker LR, Mueller BA. Pre-eclampsia in American Indians/Alaska Natives and Whites: The significance of body mass index. Matern Child Health J 2016;20:2233-2238.

20. Austin AE, Vladutiu CJ, Jones-Vessey KA, Norwood TS, Proescholdbell SK, Menard MK. Improved ascertainment of pregnancy-associtaed suicides and homicides in North Carolina. Am J Prev Med 2016;51(Suppl 3):S234-S240.

21. Bronson J, Reviere R. Pregnancy-associated deaths in Virginia due to homicides, suicides, and accidental overdoses compared with natural causes. Violence Against Women 2017;23:1620-1637.

22. Chang J, Berg CJ, Saltzman LE, Herndon J. Homicide: A leading cause of injury deaths among pregnant and postpartum women in the United States, 1991-1999. Am J Public Health 2005;95:471-477.

23. Dannenberg AL, Carter DM, Lawson HW, Ashton DM, Dorfman SF, Graham EH. Homicide and other injuries as causes of maternal death in New York City, 1987 through 1991. Am J Obstet Gynecol 1995;172:1557-1564.

24. Goldman-Mellor S, Margerison CE. Maternal drug-related death and suicide are leading causes of postpartum death in California. Am J Obstet Gynecol 2019;221:489.e1-489.e9.

25. Metz TD, Rovner P, Hoffman C, Allshouse AA, Beckwith KM, Binswanger IA. Maternal deaths from suicide and overdose in Colorado, 2004-2012. Obstet Gynecol 2016; 128:1233-1240.

26. Palladino CL, Singh V, Campbell J, Flynn H, Gold KJ. Homicide and suicide during the perinatal period. Obstet Gynecol 2011;118:1056-1063.

27. Platner M, Loucks TL, Lindsay MK, Ellis JE. Pregnancyassociated deaths in rural, nonrural, and metropolitan areas of Georgia. Obstet Gynecol 2016;128:113-120.

28. Wallace ME, Hoyert DL, Williams C, Mendola P. Pregnancy-associated homicide and suicide in 37 U.S. states with enhanced pregnancy surveillance. Am J Obstet Gynecol 2016;215:364.e1-364.e10.

29. Baldwin LM, Grossman DC, Murowchick E, et al. Trends in perinatal and infant health disparities between rural American Indians and Alaska Natives and rural Whites. Am J Public Health 2009;99:638-646.

30. Castor ML, Smyser MS, Taualii MM, Park AN, Lawson SA, Forquera RA. A nationwide population-based study identifying health disparities between American Indians/ Alaska Natives and the general populations living in select urban counties. Am J Public Health 2006;96:1478-1484.

31. Grossman DC, Baldwin LM, Casey S, Nixon B, Hollow WB, Hart LG. Disparities in infant health among American Indians and Alaska Natives in U.S. metropolitan areas. Pediatrics 2002;109:627-633.

32. Hanson JD. Understanding prenatal health care for American Indian women in a Northern Plains Tribe. J Transcult Nurs 2012;23:29-37.

33. Martin JA, Hamilton B, Osterman M, Driscoll AK. Births: Final data for 2018. Natl Vital Stat Rep 2019;68:1-47.

34. Wilder Research. American Indian infant mortality in Minnesota-Gaps in services for mothers and provider training needs: A study conducted for twin cities healthy start. 2015. Available at: https://www.wilder.org/sites/ default/files/imports/TwinCitiesHealthyStart_FinalReport_ 1-15.pdf Accessed February 8, 2020.

35. Cheng D, Horon IL. Intimate-partner homicide among pregnant and postpartum women. Obstet Gynecol 2010; 115:1181-1186. 
36. Centers for Disease Control and Prevention. The national intimate partner and sexual violence survey: 2010-2012 State report. 2017. Available at: https://www.cdc.gov/viol enceprevention/pdf/NISVS-StateReportBook.pdf?fbclid=Iw AR0yQ0QzhbsetnNFmcg3XfPZB-5N241M0o1LQurOBIN 8hEmaHijJkHGJd3U Accessed May 19, 2020.

37. Urban Indian Health Institute. Missing and murdered indigenous women and girls: A snapshot of data from 71 urban cities in the U.S. 2018. Available at: https://www.uihi .org/resources/missing-and-murdered-indigenous-womengirls Accessed May 20, 2020.

38. Koch AR, Geller SE. Addressing maternal deaths due to violence: The Illinois experience. Am J Obstet Gynecol 2017;217:556.e1-556.e6.

39. Danielson RA, Wallenborn JT, Warne DK, Masho SW. Disparities in risk factors and birth outcomes among American Indians in North Dakota. Matern Child Health J 2018;22:1519-1525.

40. Scholl L, Seth P, Kariisa M, Wilson N, Baldwin G. Drug and opioid-involved overdose deaths: United States, 20132017. MMWR Morb Mortal Wkly Rep 2019;67:14191427.

41. Howell EA, Zeitlin J. Improving hospital quality to reduce disparities in severe maternal morbidity and mortality. Semin Perinatol 2017;41:266-272.

42. Gadson A, Akpovi E, Mehta PK. Exploring the social determinants of racial/ethnic disparities in prenatal care utilization and maternal outcome. Semin Perinatol 2017;41: 308-317.

43. Howell EA. Reducing disparities in severe maternal morbidity and mortality. Clin Obstet Gynecol 2018;61: 387-399.

44. Partridge S, Balayla J, Holcroft CA, Abenhaim HA. Inadequate prenatal care utilization and risks of infant mortality and poor birth outcome: A retrospective analysis of 28,729,765 U.S. deliveries over 8 years. Am J Perinatol 2012;29:787-794.

45. Raglan GB, Lannon SM, Jones KM, Schulkin J. Racial and ethnic disparities in preterm birth among American Indian and Alaska Native women. Matern Child Health J 2016;20: 16-24.

46. Building U.S. capacity to review and prevent maternal deaths. Report from nine Maternal Mortality Review Committees. 2018. Available at: https://www.cdcfounda tion.org/sites/default/files/files/ReportfromNineMMRCs.pdf Accessed April 4, 2020.

47. American Psychiatric Association. Diagnostic and statistical manual of mental disorders, 5th ed. Arlington, VA: American Psychiatric Association Publishing, 2013.

48. Baker L, Cross S, Greaver L, Wei G, Lewis R, Healthy Start CORPS. Prevalence of postpartum depression in a Native American population. Matern Child Health J 2005; 9:21-25.

49. Mukherjee S, Fennie K, Coxe S, Madhivanan P, Trepka MJ. Racial and ethnic differences in the relationship between antenatal stressful life events and postpartum depression among women in the United States: Does provider communication on perinatal depression minimize the risk? Ethn Health 2018;23:542-565

50. Ness MN, Rosenberg KD, Abrahamson-Richards T, Sandoval AP, Weiser TM, Warren-Mears V. Stressful life events and self-reported postpartum depressive symptoms 13-24 months after live birth among non-Hispanic American Indian/Alaska Native mothers in Oregon: Results from a population-based survey. Am Indian Alsk Native Ment Health Res 2017;24:76-98.

51. Mathematica Policy Research. Addressing trauma in American Indian and Alaska Native youth. 2016. Available at: https://aspe.hhs.gov/system/files/pdf/207941/AIAN YouthTIC.PDF Accessed February 23, 2020.

52. Brown-Rice K. Examining the theory of historical trauma among Native Americans. Prof Couns 2020;3:117-130.

53. U.S. DHHS Office of Minority Health. Profile: American Indian/Alaska Native. 2018. Updated March 28, 2018. Available at: https://minorityhealth.hhs.gov/omh/browse .aspx?lvl=3\&lvlid=62 Accessed March 1, 2020.

54. Dennis JA. Birth weight and maternal age among American Indian/Alaska Native mothers: A test of the weathering hypothesis. SSM Popul Health 2018;7:004-4.

55. National Academies of Sciences, Engineering, and Medicine. Birth settings in America: Outcomes, quality, access, and choice. 2020. Available at: https://www.nap.edu/ catalog/25636/birth-settings-in-america-outcomes-qualityaccess-and-choice Accessed February 16, 2020.

56. Moaddab A, Dildy GA, Brown HL, et al. Health care disparity and pregnancy-related mortality in the United States, 2005-2014. Obstet Gynecol 2018;131:707-712.

57. Renfrew MJ, McFadden A, Bastos MH, et al. Midwifery and quality care: Findings from a new evidence-informed framework for maternal and newborn care. Lancet 2014; 384:1129-1145

58. Vedam S, Stoll K, MacDorman M, et al. Mapping integration of midwives across the United States: Impact on access, equity, and outcomes. PLoS One 2018;13:e0192523.

59. Lu MC, Chen B. Racial and ethnic disparities in preterm birth: The role of stressful life events. Am J Obstet Gynecol 2004;191:691-699.

60. Fiscella K. Racial disparity in infant and maternal mortality: Confluence of infection, and microvascular dysfunction. Matern Child Health J 2004;8:45-54.

61. Denny CH, Floyd RL, Green PP, Hayes DK. Racial and ethnic disparities in preconception risk factors and preconception care. J Womens Health 2012;21:720-729.

62. Nelson DB, Moniz MH, Davis MM. Population-level factors associated with maternal mortality in the United States, 1997-2012. BMC Public Health 2018;18:1001.

63. Rhoades DA. Commentary: disparities in data for American Indians and Alaska Natives. Am Indian Alsk Native Ment Health Res 2006;13:70-74.

64. Kilpatrick SJ. Trauma in pregnancy: An underappreciated cause of maternal death. Am J Obstet Gynecol 2017;217: 499-500.

65. Harris R, Nelson LA, Muller C, Buchwald DS. Stroke in American Indians and Alaska Natives: A systematic review. Am J Public Health 2015;105:e16-e26.

66. Hartmann W, Gone J. American Indian historical trauma: Community perspectives from two Great Plains medicine men. Am J Community Psychol 2014;54:274-288.

67. Hodge FS. No meaningful apology for American Indian unethical research abuses. Ethics Behav 2012;22:431-444.

68. Jones EJ, Haozous E, Larsson L, Moss M. Perspectives on conducting research in Indian Country. Nurs Res 2019;68: 488-493.

69. Native American Center for Excellence. Steps for conducting research and evaluation in native communities. 2010. Available at: https://www.samhsa.gov/sites/default/ files/nace-steps-conducting-research-evaluation-native-com munities.pdf Accessed May 1, 2020. 
70. NCAI Policy Research Center and MSU Center for Native Health Partnerships. "Walk softly and listen carefully": Building research relationships with tribal communities. 2012. Available at: www.ncai.org/attachments/Policy Paper_SpMCHTcjxRRjMEjDnPmesENPzjHTwhOlOWxlW OIWdSrykJuQggG_NCAI-WalkSoftly.pdf Accessed May 1, 2020.

71. Wallerstein NB, Duran B. Using community based participatory research to address health disparities. Health Promot Pract 2006;7:312-323.

72. Moher D, Liberati, A, Tetzlaff, J, Altman, DG; the PRISMA Group. Preferred reporting items for systematic reviews and meta-analyses: The PRISMA statement. Ann Intern Med 2009;151:264-269.

Address correspondence to: Jennifer L. Heck, PhD, RNC-NIC, CNE Fran and Earl Ziegler College of Nursing University of Oklahoma Health Sciences Center 1100 N. Stonewall Ave., Room 463 Oklahoma City, OK 73117

USA

E-mail: jennifer-heck@ouhsc.edu 